\title{
Anthrovision
}

Vaneasa Online Journal

$3.2 \mid 2015$

Dilemmes actuels de l'ethnographe à la caméra

\section{Editorial Anthrovision issue 3.2}

\section{Roger Canals}

\section{OpenEdition}

\section{Journals}

Electronic version

URL: http://journals.openedition.org/anthrovision/1961

DOI: 10.4000/anthrovision.1961

ISSN: 2198-6754

\section{Publisher}

VANEASA - Visual Anthropology Network of European Association of Social Anthropologists

\section{Electronic reference}

Roger Canals, «Editorial Anthrovision issue 3.2 », Anthrovision [Online], 3.2 | 2015, Online since 10 August 2016, connection on 23 September 2020. URL : http://journals.openedition.org/anthrovision/ 1961 ; DOI : https://doi.org/10.4000/anthrovision. 1961

This text was automatically generated on 23 September 2020 .

(c) Anthrovision 


\title{
Editorial Anthrovision issue 3.2
}

\author{
Roger Canals
}

Dear reader,

2 For the second issue of 2015, we are happy to present you with a set of articles written by young scholars who confront, often for the first time, the theoretical and methodological challenges of Visual Anthropology. We strongly believe that making this kind of work accessible is one of the main objectives of our journal, which aims to be a platform for publishing good research carried out by established and emergent scholars alike.

3 One of the reasons why these articles are worth publishing is because they revisit many of the classical issues of Visual Anthropology and ethnographic cinema, but from original angles. In other words, these texts permit us to reconnect with the very theoretical and ethical foundations of the discipline which are only rarely made explicit in works by senior researchers. They give us the opportunity to feel (again) what it means to do ethnography with visuals for the first time.

4 The origins of this volume dates back to 2014 when the first colloquium Rencontres Annuelles d'Ethnographie was held at the Ecole des Hautes Etudes en Sciences Sociales of Paris. Many of the articles that you will find in this volume are revised versions of papers presented at that conference.

5 The volume starts with an incisive introduction by Jonathan Larcher and Noémie Oxley. They provide an excellent overview of the texts of Leresche, García de Teresa and Poupin, situating them within the contemporary debates of Visual Anthropology. Leresche's article tells us about the experience of filming a group of male musicians. She adopts a critical and reflexive attitude to analyse how hierarchies are negotiated throughout the research process. García de Teresa focuses on the reception of visual material. Based on an ethnography in Mexico, he tackles the question of the reinterpretation of the research outcomes by those who have been involved in it. Finally, Perrine Poupin writes about her research on public political demonstrations in Moscow. She describes how the images that she took establish a dialogue with those obtained by other artists or activists, thus giving birth to a "communauté d'enquète" (a community of inquiry). The volume concludes with an excellent text by Christian 
Lallier in which he offers some reflections regarding the ambivalent position -both in epistemological and ethical terms- of the visual anthropologist in the field. 